\title{
Seroprevalence of malaria in inhabitants of the urban zone of
} Antananarivo, Madagascar

Olivier Domarle*1, Romy Razakandrainibe ${ }^{1}$, Emma Rakotomalala ${ }^{1}$, Laurence Jolivet ${ }^{2}$, Rindra Vatosoa Randremanana ${ }^{1}$, Fanjasoa Rakotomanana ${ }^{1}$, Charles Emile Ramarokoto ${ }^{1}$, Jean-Louis Soares ${ }^{1}$ and Frédéric Ariey ${ }^{3}$

\author{
Address: ${ }^{1}$ Institut Pasteur de Madagascar, Antananarivo, Madagascar, ${ }^{2}$ Ecole Nationale des Sciences Géographiques, Marne la Vallée, France and \\ ${ }^{3}$ Institut Pasteur du Cambodge, Phnom Penh, Cambodia \\ Email: Olivier Domarle* - domarle@pasteur.mg; Romy Razakandrainibe - romy@pasteur.mg; Emma Rakotomalala - emma@pasteur.mg; \\ Laurence Jolivet - ljolivet@ensg.ign.fr; Rindra Vatosoa Randremanana - rrandrem@pasteur.mg; Fanjasoa Rakotomanana - fanja@pasteur.mg; \\ Charles Emile Ramarokoto - charlesr@pasteur.mg; Jean-Louis Soares - jlsoares@pasteur.mg; Frédéric Ariey - fariey@pasteur-kh.org \\ * Corresponding author
}

Published: 10 November 2006

Malaria Journal 2006, 5:106 doi:10.1/86/1475-2875-5-106

This article is available from: http://www.malariajournal.com/content/5/I/I06

(c) 2006 Domarle et al; licensee BioMed Central Ltd.

This is an Open Access article distributed under the terms of the Creative Commons Attribution License (http://creativecommons.org/licenses/by/2.0), which permits unrestricted use, distribution, and reproduction in any medium, provided the original work is properly cited.
Received: 23 June 2006

Accepted: 10 November 2006

\begin{abstract}
Background: Antananarivo, the capital of Madagascar, is located at an altitude of over I,200 m. The environment at this altitude is not particularly favourable to malaria transmission, but malaria nonetheless remains a major public health problem. The aim of this study was to evaluate exposure to malaria in the urban population of Antananarivo, by measuring the specific seroprevalence of Plasmodium falciparum.

Methods: Serological studies specific for $P$. falciparum were carried out with an indirect fluorescent antibody test (IFAT). In a representative population of Antananarivo, I,059 healthy volunteers were interviewed and serum samples were taken.

Results: The seroprevalence of $\lg G+\lg A+\lg M$ was $56.1 \%$ and that of $\lg M$ was $5.9 \%$. The major risk factor associated with a positive IgG+lgA+IgM IFAT was travel outside Antananarivo, whether in the central highlands or on the coast. The abundance of rice fields in certain urban districts was not associated with a higher seroprevalence.

Conclusion: Malaria transmission levels are low in Antananarivo, but seroprevalence is high. Humans come into contact with the parasite primarily when travelling outside the city. Further studies are required to identify indigenous risk factors and intra-city variations more clearly.
\end{abstract}

\section{Background}

Antananarivo, the capital of Madagascar, is located on hills in the middle of the Central Highlands, at an altitude of between 1,200 and 1,400 $\mathrm{m}$. The city and its surroundings include 1,700,000 inhabitants (2001 census), corre- sponding to about $10 \%$ of the national population. The Antananarivo plain is covered by vast areas of irrigated rice fields, which are potential breeding sites for malaria vectors. Some of the seedier districts in the middle of town have zones that flood easily, favouring mosquito breed- 
ing. At the beginning of the 1980s, Anopheles funestus reappeared in the Central Highlands of Madagascar [1-3], from which it had disappeared in the 1950s [4]. New epidemic episodes appeared in the middle of the 1980s [5-7], causing several tens of thousands of deaths [8]. Two surveys carried out in Antananarivo in 2003 showed, by biological examinations, that less than $2 \%$ of all cases of fever were confirmed to be malaria. About $80 \%$ of the confirmed cases had travelled outside the city to areas exposed to malaria in the weeks preceding the survey, the remaining $20 \%$ of cases being cases of indigenous malaria due to local transmission [9]. Imported cases outnumber cases of indigenous malaria, and studies have shown only low levels of indigenous malaria transmission. The mosaic nature of the Antananarivo environment exposes the inhabitants of certain zones to the risk of malaria outbreaks.

The history of contact between humans and Plasmodium falciparum was examined by measuring seroprevalence in a representative population from the urban zone, to identify factors associated with exposure to malaria.

\section{Methods \\ Population study}

The study was conducted using existing serum samples from inhabitants of Antananarivo who had been enrolled in February 2004 for a study on hepatitis C. Volunteers were selected by cluster sampling with two degrees of freedom, based on the cluster sampling method used in immunisation coverage programmes [10]. This mode of random and cluster sampling yielded a cohort of subjects representative of the population of Antananarivo. Seventy clusters of 13 to 18 people were selected for this investigation, to maximise the effect of clusters and displacements (as described in [10]). Once informed consent had been obtained, the subjects were interviewed and serum samples were obtained from blood collected in dry tubes for biological analyses. A questionnaire was designed to evaluate the influence of associated factors: the number of journeys involving at least one night outside the city in the last six months, number of antimalarial treatments in the last six months and level of schooling (to evaluate socioeconomic status).

\section{Screening for antibodies specific for $\mathbf{P}$. falciparum}

For antibody screening, the indirect fluorescent antibody test (IFAT) was used $[11,12]$. Slides were coated with the Palo Alto strain of $P$. falciparum from continuous in vitro culture. Serum samples, at successive dilutions between $1 /$ 64 and $1 / 4,096$, were incubated with the parasites on the slide. A reaction with the $1 / 64$ dilution is generally regarded as the threshold for a positive reaction [13]. The antibody-antigen complex was detected using sheep $\mathrm{F}\left(\mathrm{ab}^{\prime}\right) 2$ anti-human-IgM conjugated with fluorescein iso- thiocyanate (FITC), or sheep $(\mathrm{H}+\mathrm{L})$ anti-humanIgG+IgA+IgM conjugated with FITC (Bio-Rad, France). All incubations were performed at room temperature, in a dark, humid chamber, for 45 minutes. Between incubations, slides were washed three times in phosphate-buffered saline. All tests were done in parallel with seropositive and seronegative control samples from the serum libraries of the laboratory. Slides were examined with an epifluorescence microscope. Antibody concentration was determined semi-quantitatively, by noting the highest dilution factor at which the serum gave fluorescent spots on incubation with the parasites.

Data were analysed in two different ways. A dichotomous classification of samples as seronegative or seropositive was used for analyses of seroprevalence and statistical analysis. To take into account the range of antibody concentrations and transformed individual into collective data, subjects were assigning into categories, according to common criteria, and the geometric mean of antibody rates (GMAR) were calculated according to the following formula $\left(\mathrm{n}_{\mathrm{x}}\right.$ is the number of subjects positive at the dilution rate of $x ; d_{x}$ is the dilution factor for the dilution rate of $x$, for example, the $d_{x}$ value for $1 / 64$ is 64 ; for sera negative for all dilution rates, $\log \left(\mathrm{d}_{\mathrm{x}}\right)=1$ ):

$$
\text { GMAR }=10 \frac{\sum \mathrm{n}_{\mathrm{x}} \cdot \log \left(\mathrm{d}_{\mathrm{x}}\right)}{\sum \mathrm{n}_{\mathrm{x}}}
$$

\section{Geographical analysis}

Rice fields are thought to be the most favourable environment for the development of malaria vectors in the ecosystems of Antananarivo [1-3,7]. Two types of image were used to identify rice fields [14]. The Landsat Enhanced Thematic Mapper (ETM+) image was acquired on May 2000 and radar images (Envisat) were acquired in January and July 2004. Rice fields differ from other types of vegetation in continually changing state over the course of the year.

Landsat images were enhanced by creating a colour composite image from the seven spectral bands of the original image, to make it easier to recognise objects on the ground. This was achieved by assigning bands to one of the three channels (blue, red, green). This makes it possible to calibrate various responses on the image: differences in colour and texture are associated with different classes of land cover. Principal component analysis (PCA) was then used to create neo-channels with more than $95 \%$ of information in the first axis, PCA1 $[15,16]$.

Two periods of field work were carried out. The first period was used to identify training sites and test sites. The GPS (Gerographical Positionning System) co-ordinates of the rice fields visited during these field studies are given. 
The second period of field work was used to check that the features on the ground corresponded to the images obtained. The training sites were digitised and supervised classification by the maximum likelihood method was used to generate a map of rice fields. The accuracy of this classification accuracy was estimated, using the Kappa coefficient [17]. The test sites were used to produce a confusion matrix, for assessing the overall accuracy of the land cover classification map.

Radar images were calibrated before absolute georeferencing. Image enhancement was designed to reduce speckling but to preserve accuracy. Adaptive filters were applied to ensure the highest possible image quality. Landscape changes between January and July were compared by visual image interpretation and backscatter coefficient analysis $[18,19]$. A rice field index was calculated by dividing the area under rice by the area of the "Fokontany", the basic administrative district in the city [20].

\section{Statistical analysis}

Values of $p<0.05$ were considered significant in all statistical analyses. Univariate analysis was carried out with Pearson's chi-squared test as implemented in EPI-info software. $\mathrm{Chi}^{2}$ tests were used to compare qualitative variables. Multivariate analysis was carried out by means of backward stepwise logistic regression, using SPSS ${ }^{\circledast}$ software (version 11.5). The dependent variable was positive IgG+IgA+IgM tests for malaria. Variables with $p$ values below 0.2 in univariate analysis were introduced into the model and kept constant during the first step.

\section{Results \\ Characteristics of the cohort}

The study was carried out on 1,059 subjects ( 70 clusters of 13 to 18 subjects) with a male/female sex ratio of 0.59 . The mean age of the subjects was $29.56 \pm 17.66$ years. Most (89.6\%) had settled in Antananarivo in the four years before the survey. The investigators asked the subjects how many times they had spent at least one night outside of Antananarivo in the previous six months: $28.14 \%$ had spent at least one night outside the city on journeys to the Central Highlands (17.75\%) or coastal zones $(10.39 \%)$. Patients were asked about the frequency of malaria treatment during the previous six months: $82.63 \%$ had no malaria treatment, $12.65 \%$ had one course of malaria treatment and $4.72 \%$ had more than one course of malaria treatment. Socio-economic status was estimated, using a classification based on education level: no schooling (4.63\%), primary school level $(35.41 \%)$, secondary school level $(49.01 \%)$ and post-secondary studies (10.95\%).

\section{Rice field index}

The rice field index, calculated from satellite images, was used to classify city districts according to the percentage of the surface area suitable for potential anopheline mosquito breeding sites (Figure 1). Its value varied from $0 \%$ to $86 \%$ (median $=4.76 \%$; first quartile $0 \%$; third quartile = $26.99 \%)$.

\section{Serology}

Table 1 shows the results for IgG+IgA+IgM testing. The seroprevalence was $56.10 \%$. The seroprevalence in men was significantly higher than that in women $(60.1 \%$ and $53.7 \%$, respectively; chi ${ }^{2}$ test, $\left.p=0.044\right)$. The serological prevalence of IgG+IgA+IgM increased significantly with age (under or over 15 years of age, chi ${ }^{2}$ test, $p<0.0001$ ). Univariate analysis (Table 1 ) showed significant associations between IgG+IgA+IgM-positive IFAT, travel outside the city, and rice field index. Travels outside the city were

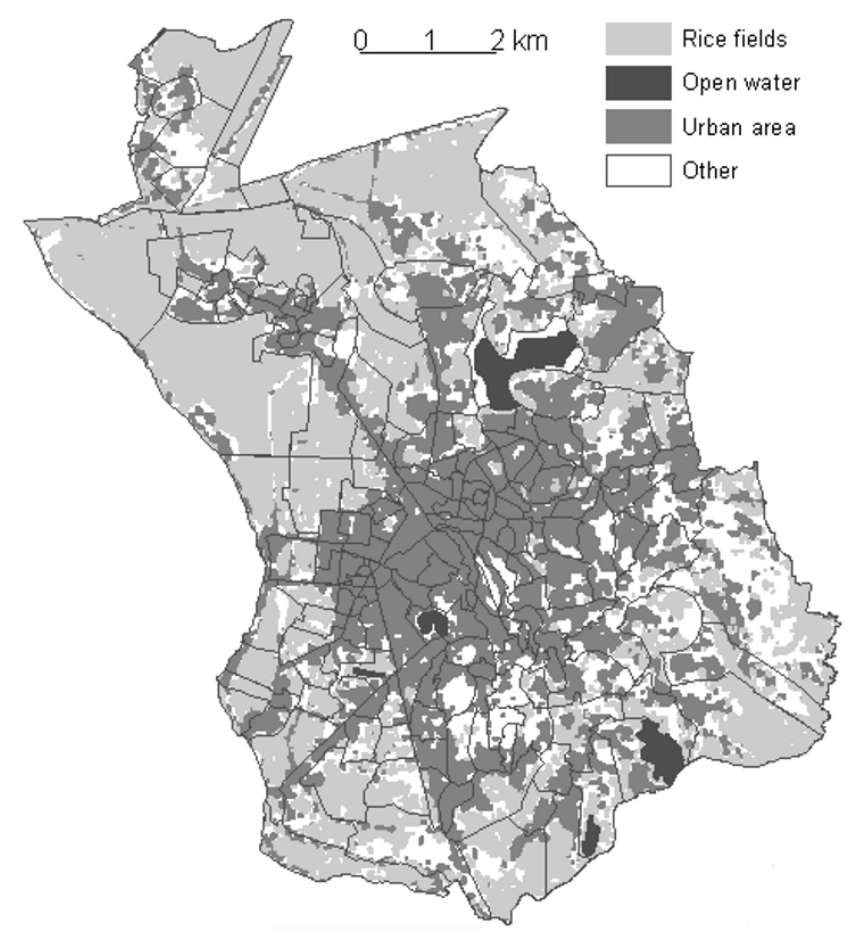

\section{Figure I}

Map of Antananarivo with its 192 districts ("fonkontany" in Malagasy) and rice fields located by satellite images. A comparison of satellite images in different seasons made it possible to locate the rice fields (in light grey) and to differentiate them from the other types of vegetation (in white: bare soil, vegetation, other crops). Districts are delimited as indicated on the map. For each district, rice field index was calculated by dividing the area under rice by the area of the entire district. 
associated with a higher seroprevalence, and the GMAR of those who travelled (coast or Central Highlands) was higher than that of subjects who did not travel (GMAR coast group $=29.3 ;$ GMAR Central Highlands group $=$ 30.2 ; GMAR for the group that did not travel $=16.1$ ). Seroprevalence was analysed as a function of rice field index. A significant difference was observed between the subjects of the third quartile (rice field index $>26.99 \%$ ) and the other subjects, with people living in districts with a high rice field index having a lower IgG+IgA+IgM prevalence. Sex, socio-economic level, history of travel outside Antananarivo and rice field index were included in a logistic regression model. Multivariate analysis confirmed that age, travelling outside Antananarivo and rice field index were significantly associated with the presence of
IgG+IgA+IgM (Table 2). The seroprevalence of IgM was about $5.85 \%$, and was not associated with other variables.

\section{Discussion}

Sampling was designed to ensure that the cohort of subjects enrolled was representative of the population of Antananarivo. However, the male/female sex ratio was 0.59 . This may be explained by the logistics of sample collection, which occurred when men were at work. Men travelled outside Antananarivo significantly more frequently than women (data not shown), potentially accounting for the significantly larger number of male carriers of $P$. falciparum antibodies. As expected, age was significantly related to an increase in the frequency of positive IFAT results. This relationship is accounted for by

Table I: Factors associated with IgG+IgA+IgM seroprevalence

\begin{tabular}{|c|c|c|c|c|c|}
\hline & & \multicolumn{4}{|c|}{ P. falciparum IgG+IgA+IgM } \\
\hline & & $\mathbf{n}$ & negative & positive & $P$ \\
\hline \multicolumn{2}{|l|}{ Entire cohort } & 1,059 & $43.9 \%$ & $56.1 \%$ & \\
\hline \multirow[t]{3}{*}{ Sex } & Sex ratio $($ male/female $)=0.59$ & & & & \\
\hline & Male & 391 & $14.7 \%$ & $22.2 \%$ & 0.044 \\
\hline & Female & 668 & $29.2 \%$ & $33.9 \%$ & \\
\hline \multirow[t]{3}{*}{ Age } & Mean age $=29.56 \pm 17.66$ years & & & & \\
\hline & $<15$ years & 251 & $12.9 \%$ & $10.8 \%$ & $<0.0001$ \\
\hline & $\geq 15$ years & 808 & $31.0 \%$ & $45.3 \%$ & \\
\hline \multirow[t]{4}{*}{ Social class } & No schooling & 49 & $2.2 \%$ & $2.5 \%$ & NS \\
\hline & Primary school level & 375 & $16.8 \%$ & $18.6 \%$ & \\
\hline & Secondary school level & 519 & $20.3 \%$ & $28.7 \%$ & \\
\hline & Post-secondary studies & 116 & $4.6 \%$ & $6.3 \%$ & \\
\hline \multirow{3}{*}{$\begin{array}{l}\text { Travel outside city } \\
\text { (previous } 6 \text { months) }\end{array}$} & No travel & 761 & $33.4 \%$ & $38.4 \%$ & 0.021 \\
\hline & Travel to Central Highlands & 188 & $6.4 \%$ & $11.3 \%$ & \\
\hline & Travel to the coast & 110 & $4.1 \%$ & $6.3 \%$ & \\
\hline \multirow{3}{*}{$\begin{array}{l}\text { Malaria episodes } \\
\text { (previous } 6 \text { months) }\end{array}$} & 0 declared episodes, no treatment & 875 & $36.5 \%$ & $46.2 \%$ & NS \\
\hline & I declared episode with treatment & 134 & $5.7 \%$ & $7.0 \%$ & \\
\hline & More than I episode & 50 & $1.8 \%$ & $2.9 \%$ & \\
\hline \multirow[t]{2}{*}{ Rice field index } & Lower than $26.98 \%$ & 785 & $29.6 \%$ & $44.5 \%$ & $<0.0001$ \\
\hline & Higher than $26.99 \%$ (last quartile) & 274 & $14.3 \%$ & $11.6 \%$ & \\
\hline \multicolumn{2}{|c|}{$\begin{array}{l}\text { Subjects living in the city for more than } 4 \text { years and had not } \\
\text { travelled outside the city in the previous } 6 \text { months }\end{array}$} & 690 & $46.5 \%$ & $53.5 \%$ & \\
\hline \multirow[t]{3}{*}{ Sex } & Sex ratio $($ male $/ \mathrm{female})=0.49$ & & & & \\
\hline & Male & 226 & $14.1 \%$ & $18.7 \%$ & NS \\
\hline & Female & 464 & $32.5 \%$ & $34.8 \%$ & \\
\hline \multirow[t]{3}{*}{ Age } & Mean age $=30.25 \pm 18.07$ years & & & & \\
\hline & $<15$ years & 165 & $13.3 \%$ & $10.6 \%$ & 0.006 \\
\hline & $\geq 15$ years & 525 & $33.2 \%$ & $42.9 \%$ & \\
\hline \multirow[t]{2}{*}{ Rice field index } & Lower than $26.98 \%$ & 512 & $32.3 \%$ & $41.9 \%$ & 0.008 \\
\hline & Higher than $26.99 \%$ (last quartile) & 178 & $14.2 \%$ & $11.6 \%$ & \\
\hline
\end{tabular}


Table 2: Multivariable analysis of the variables associated with IgG+lgA+lgM seropositivity

\begin{tabular}{|c|c|c|c|}
\hline & Coef. & Cl 95\% & $\boldsymbol{P}$ \\
\hline \multicolumn{4}{|l|}{ Entire cohort. $n=1,059$} \\
\hline Age $(<15$ vs $\geq 15$ years $)$ & 1.012 & {$[1.0051 .019]$} & 0.001 \\
\hline Travel outside city (previous 6 months; no travel vs travel) & 1.360 & {$[1.0261 .801]$} & 0.032 \\
\hline Rice field index (low vs high (last quartile)) & 0.554 & {$\left[\begin{array}{lll}0.424 & 0.725\end{array}\right]$} & $<0.001$ \\
\hline \multicolumn{4}{|c|}{$\begin{array}{l}\text { Subjects living in the city for more than } 4 \text { years and had not travelled outside the city in the } \\
\text { previous } 6 \text { months, } n=690\end{array}$} \\
\hline Age $(<15$ vs $\geq 15$ years $)$ & 1.013 & {$[1.0041 .022]$} & 0.004 \\
\hline Rice field index (low vs high (last quartile)) & 0.583 & {$[0.4190 .810]$} & 0.001 \\
\hline
\end{tabular}

the increase in the cumulative risk of human/parasite contact with age, and by travelling outside the city being more common in subjects over the age of 15 years than in younger subjects (chi-squared test, $p<0.05$, data not shown).

Rice fields are thought to be the principal location of anopheline mosquito breeding sites in Antananarivo [13,7]. However, data show an inverse relationship between rice field index and seroprevalence for IgG+IgA+IgM. IgG+IgA+IgM rates are in major part determined by IgG. It is difficult to estimate the relationship between the rates of IgG and the intensity and history of human-parasite contact, particularly if this contact is regular. It is commonly thought that IgG can be detected several years after contact with the parasite. However, Phase I trials of malaria vaccines have shown that most subjects become seronegative within six to eight months of the last injection [21-23], or remains detectable 12 months after immunization in only a minority of subjects [24]. In this present study, when data were analysed with subjects limited to those who had lived in Antananarivo for more than four years and who had not travelled outside the city in the six months before the investigation, the inverse relationship between rice field index and IgG+IgA+IgM prevalence in IFAT persisted. It is possible that travelling outside the city more than six months before the study may still have had a very strong effect on IgG rates.

The rice field index calculated for each district did not take into account the distance between mosquito breeding sites and dwellings. The level of transmission, the risk of malaria and seroprevalence may depend on the distance between mosquito breeding sites [25-27], rather than the total surface area covered by such sites.

Subjects with a higher level of education (secondary school level or higher) were significantly more likely to have travelled outside the city in the previous six months than less educated subjects (no schooling or primary school only). However, the least educated subjects lived in the districts with the highest rice field index (data not shown), when those with the highest social standing lived in the most salubrious districts, with a low rice field index, but frequently travelled outside the city, resulting in higher risk of malaria in this group. However, multivariate analysis identified no significant influence of educational level on the relationship between rice field index and IgG+IgA+IgM prevalence. A recent study in Accra and Kumasi, Ghana, showed that low socio-economic status was associated with a high prevalence of malaria [28]. Malaria transmission was higher in Accra than in Antananarivo. Local malaria transmission in Antananarivo seems to be a minor risk that it may be difficult to distinguish. Other studies have reported a 'paddies paradox' based on parasitological studies in different malaria transmission areas [29-34]. However, the context is very different for Antananarivo, with its urban zone (unfavourable for malaria vectors) and a mosaic of rice fields (more suitable for the breeding of Anopheles than the urban environment). The causal factors are therefore unlikely to be the same.

Unexpectedly, the study showed that a high density of potential larval habitats was associated with a lower prevalence of specific $P$. falciparum antibodies. However, this relationship was skewed by i) journeys outside the city in the years preceding this study (frequency and duration), ii) differences in the frequency of journeys outside the city between social classes, iii) the pattern of settlement in the city, which depends on socio-economic status and sanitary conditions, iv) the fact that the rice field index of the district did not take into account the distance between the larval habitat and the dwelling places of the enrolled subjects.

Like other studies [9,35-38], this study showed that travels outside the city were a major risk factor for malaria. However, this study also reveals the peculiarity of the urban environment for malaria. Urban malaria occurs in a particular context, and the rules governing its occurrence may differ from those described for the rural environment 
[39]. Nowadays, more than half the African population lives in cities. Better knowledge of the urban context is necessary to optimise strategies to fight malaria.

\section{Authors' contributions}

FA initiated this project and designed the study whilst at Institut Pasteur de Madagascar. J-LS and CER were the investigators in the hepatitis $\mathrm{C}$ survey leading to this study of malaria. They were responsible for statistical analysis of the data. FR, RVR and LJ carried out all the geographical parts of the study. RR and ER carried out the IFAT tests. OD was the principal investigator. He analysed and interpreted the data and wrote the manuscript. All the authors have revised and approved the final manuscript.

\section{Acknowledgements}

We thank all the medical staff involved in the hepatitis $C$ survey that gave rise to this study on malaria. We also thank the patients who agreed to take part in the study. The ACIP (Action Concertée Inter-Pasteurienne) project and the European Spatial Agency for Envisat image acquisition (CATI-2320 project) financed the purchase of the satellite images. The serum library was compiled by the team of the Unité de Virologie, directed by Dr. Dominique Rousset.

\section{References}

I. Fontenille D, Rakotoarivony I: Reappearance of Anopheles funestus as a malaria vector in the Antananarivo region, Madagascar. Trans R Soc Trop Med Hyg 1988, 82:644-645.

2. Severini C, Fontenille D, Ramiakajato MR: Preliminary study on malaria transmission at the end of the rainy season in Mahitsy near Tananarive. Arch Inst Pasteur Madagascar 1990, 57:323-333.

3. Laventure S, Mouchet J, Blanchy S, Marrama L, Rabarison P, Andrianaivolambo L, Rajaonarivelo E, Rakotoarivony I, Roux J: Rice: source of life and death on the plateaux of Madagascar. Sante 1996, 6:79-86.

4. Mouchet J, Blanchy S, Rakotonjanabelo A, Ranaivoson G, Rajaonarivelo $E$, Laventure S, Rossella M, Aknouche F: Stratification épidémiologique du paludisme à Madagascar. Arch Inst Pasteur Madagascar 1993, 60:50-59.

5. Lepers JP, Deloron P, Andriamagatiana-Rason MD, Ramanamirija JA, Coulanges P: Newly transmitted Plasmodium falciparum malaria in the central highland plateaux of Madagascar: assessment of clinical impact in a rural community. Bull World Health Organ 1990, 68:217-222.

6. Lepers JP, Fontenille D, Rason MD, Chougnet C, Astagneau P, Coulanges $\mathrm{P}$, Deloron P: Transmission and epidemiology of newly transmitted falciparum malaria in the central highland plateaux of Madagascar. Ann Trop Med Parasitol 1991, 85:297-304

7. Mouchet J, Laventure S, Blanchy S, Fioramonti R, Rakotonjanabelo A, Rabarison $P$, Sircoulon J, Roux J: La reconquête des Hautes Terres de Madagascar par le paludisme. Bull Soc Pathol Exot 1997, 90:162-168.

8. Lepers JP, Deloron P, Fontenille D, Coulanges P: Reappearance of falciparum malaria in central highland plateaux of Madagascar. Lancet 1988, I:586.

9. Rabarijaona LP, Ariey F, Matra R, Cot S, Raharimalala LA, Ranaivo LH, Le Bras J, Robert V, Randrianarivelojosia M: Low autochtonous urban malaria in Antananarivo (Madagascar). Malar J 2006, 5:27.

10. Henderson RH, Sundaresan T: Cluster sampling to assess immunization coverage: a review of experience with a simplified sampling method. Bull World Health Organ 1982, 60:253-260.

II. Sulzer AJ, Wilson M, Hall EC: Indirect fluorescent-antibody tests for parasitic diseases. V. An evaluation of a thick-smear antigen in the IFA test for malaria antibodies. Am J Trop Med Hyg 1969, 18:199-205.
12. Perlmann H, Berzins K, Wahlgren M, Carlsson J, Bjorkman A, Patarroyo ME, Perlmann P: Antibodies in malarial sera to parasite antigens in the membrane of erythrocytes infected with early asexual stages of Plasmodium falciparum. J Exp Med 1984, 159:1686-1704

13. Lepers JP, Andriamangatiana-Rason MD, Ramanamirija JA, Coulanges $P$ : Etude des sérologies palustres en immunofluorescence indirecte chez des enfants de la région de Tananarive 1987. Arch Inst Pasteur Madagascar 1988, 54: I43-149.

14. Hugue-Jones M: Application of remote sensing to the identification of the habitats of parasites and disease vectors. Parasitol Today 1989, 5:8.

15. Bonn F, Rochon G: Précis de télédétection: Principe et méthode. Volume I. Presse Universitaire de Québec/AUPELF edition; 1992:512.

16. Girard M-C, Girard C: Traitement des données en télédétection Dunod edn. Paris; 1999.

17. Eastman JR: Guide to GIS and Image Processing Idrisi Production edn: Clark University; 1999.

18. Ribbes F: Utilisation des données radar pour le suivi des rizières : cartographie, suivi de croissance et estimation du rendement. In Thesis Université Paul Sabatier, Toulouse III; 1998.

19. Determination of rice planting area in Japan using remote sensing data [http://www.gisdevelopment.net/]

20. Jeanne I: Malaria and schistosomiasis: two examples using systems of geographical information and teledetection in Madagascar. Bull Soc Pathol Exot 2000, 93:208-2I4.

21. Audran R, Cachat M, Lurati F, Soe S, Leroy O, Corradin G, Druilhe P, Spertini F: Phase I malaria vaccine trial with a long synthetic peptide derived from the merozoite surface protein 3 antigen. Infect Immun 2005, 73:8017-8026.

22. Malkin EM, Diemert DJ, McArthur JH, Perreault JR, Miles AP, Giersing BK, Mullen GE, Orcutt A, Muratova O, Awkal M, et al.: Phase I clinical trial of apical membrane antigen I: an asexual bloodstage vaccine for Plasmodium falciparum malaria. Infect Immun 2005, 73:3677-3685.

23. Nardin EH, Oliveira GA, Calvo-Calle JM, Wetzel K, Maier C, Birkett AJ, Sarpotdar P, Corado ML, Thornton GB, Schmidt A: Phase I testing of a malaria vaccine composed of hepatitis $B$ virus core particles expressing Plasmodium falciparum circumsporozoite epitopes. Infect Immun 2004, 72:651 9-6527.

24. Druilhe P, Spertini F, Soesoe D, Corradin G, Mejia P, Singh S, Audran $R$, Bouzidi A, Oeuvray C, Roussilhon C: A malaria vaccine that elicits in humans antibodies able to kill Plasmodium falciparum. PLOS Med 2005, 2:e344.

25. Trape JF, Zoulani A: Malaria and urbanization in central Africa: the example of Brazzaville. Part II: Results of entomological surveys and epidemiological analysis. Trans $R$ Soc Trop Med Hyg 1987, 81:10-18.

26. Trape JF, Lefebvre-Zante E, Legros F, Ndiaye G, Bouganali H, Druilhe P, Salem G: Vector density gradients and the epidemiology of urban malaria in Dakar, Senegal. Am J Trop Med Hyg 1992, 47:181-189.

27. Thompson R, Begtrup K, Cuamba N, Dgedge M, Mendis C, GamageMendis A, Enosse SM, Barreto J, Sinden RE, Hogh B: The Matola malaria project: a temporal and spatial study of malaria transmission and disease in a suburban area of Maputo, Mozambique. Am J Trop Med Hyg 1997, 57:550-559.

28. Klinkenberg E, McCall PJ, Wilson MD, Akoto AO, Amerasinghe FP Bates I, Verhoeff FH, Barnish G, Donnelly MJ: Urban malaria and anaemia in children: a cross-sectional survey in two cities of Ghana. Trop Med Int Health 2006, I I:578-588.

29. Faye O, Fontenille D, Gaye O, Sy N, Molez JF, Konate L, Hebrard G, Herve JP, Trouillet J, Diallo S, Mouchet J: Malaria and rice growing in the Senegal River delta (Senegal). Ann Soc Belg Med Trop 1995, 75:179-189.

30. Dossou-Yovo J, Doannio JM, Diarrassouba S, Chauvancy G: The impact of rice fields on malaria transmission in the city of Bouake, Cote d'Ivoire. Bull Soc Pathol Exot 1998, 9 1:327-333.

31. ljumba JN, Lindsay SW: Impact of irrigation on malaria in Africa: paddies paradox. Med Vet Entomol 200I, I5:I-II.

32. ljumba JN, Shenton FC, Clarke SE, Mosha FW, Lindsay SW: Irrigated crop production is associated with less malaria than traditional agricultural practices in Tanzania. Trans $R$ Soc Trop Med Hyg 2002, 96:476-480. 
33. Marrama L, Jambou R, Rakotoarivony I, Leong Pock Tsi JM, Duchemin JB, Laventure S, Mouchet J, Roux J: Malaria transmission in Southern Madagascar: influence of the environment and hydroagricultural works in sub-arid and humid regions. Part I. Entomological investigations. Acta Trop 2004, 89: 193-203.

34. Mutero CM, Kabutha C, Kimani V, Kabuage L, Gitau G, Ssennyonga J, Githure J, Muthami L, Kaida A, Musyoka L, Marie E, Oganda M: A transdisciplinary perspective on the links between malaria and agroecosystems in Kenya. Acta Trop 2004, 89: I7I-I86.

35. Ng'andu NH, Watts TE, Wray J, Siziya S: The role of some risk factors of exposure to malaria in determining the outcome of the immunofluorescent antibody test in an urban population. Trans R Soc Trop Med Hyg 1989, 83:480-483.

36. Watts TE, Wray JR, Ng'andu NH, Draper CC: Malaria in an urban and a rural area of Zambia. Trans R Soc Trop Med Hyg 1990, 84:196-200.

37. Koram KA, Bennett S, Adiamah JH, Greewood BM: Socio-economic risk factors for malaria in peri-urban area of the Gambia. Trans R Soc Trop Med Hyg 1995, 89: I46-150.

38. Jambou R, Tombo ML, Raharimalala L, Rakotonjanabelo A, Rabe $T$, Laventure $S$, Boisier P: Le paludisme à Antananarivo: évaluation d'une situation post-épidémique. Cahiers Sante 1998, 8:257-264.

39. Robert V, Macintyre K, Keating J, Trape JF, Duchemin JB, Warren M, Beier JC: Malaria transmission in urban sub-Saharan Africa. Am J Trop Med Hyg 2003, 68:169-176.

Publish with Bio Med Central and every scientist can read your work free of charge

"BioMed Central will be the most significant development for disseminating the results of biomedical research in our lifetime. "

Sir Paul Nurse, Cancer Research UK

Your research papers will be:

- available free of charge to the entire biomedical community

- peer reviewed and published immediately upon acceptance

- cited in PubMed and archived on PubMed Central

- yours - you keep the copyright

Submit your manuscript here:

http://www.biomedcentral.com/info/publishing_adv.asp
BioMedcentral 